\title{
Characterization of adult male albino rat mammary gland: a histological and serological study
}

Zienab A. Gouda*, Samah M. Ahmed and Nabila M. Elghonaimy

*Correspondence: dr_zienab@ hotmail.com

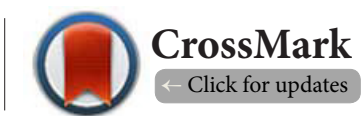

Department of Histology and Cell Biology, Faculty of Medicine, Zagazig University, Zagazig 44519, Egypt.

\begin{abstract}
Background: In male animal of most mammals, a rudimentary mammary structure is encountered; however the male albino rat mammary gland structure is unique in displaying marked development and showing great sexual dimorphism.

Aim of the work: Detection of causes and importance of the unique histological and serological features of adult male albino rat's mammary gland.

Materials and methods: Twenty eight adult healthy albino rats were utilized and separated into male and female groups. Blood samples were collected for serological analysis of estradiol $17 \beta$ (ERB), progesterone (PRA) and prolactin (PRL) hormones. Small pieces of the right mammary glands were submitted to tissue epidermal growth factor (EGF), insulin growth factor-I (IGF-I) and transforming growth factor- $\alpha$ (TGF $\alpha$ ) analysis. Paraffin sections were prepared for histological; Hematoxylin and Eosin (H\&E) and Masson's trichrome (MT) staining and immunohistochemical stain of estrogen (ER) and progesterone (PR) receptors. The left glands were prepared for whole mount carmine alum stain technique.

Results: The male group revealed a high statistically significant decrease of PRL hormone and a statistically significant decrease of ERB hormone levels in comparison to female group. Progesterone hormone serum level showed no statistically significant difference between both groups. A statistically significant decrease regarding tissue EGF, IGF I and TGF $\alpha$ in male group was detected. Whole mount technique showed a remarkable glandular growth of the male mammary glands with elaborated lobulo-alveolar structure. Short thick interlobular ducts, prominent lateral buds and large terminal lobules were seen. The histological examination of male group revealed less developed stroma in the form of thin capsule and septa, thin periductal fibrous stroma. Lobulo-alveolar structures were predominant in male gland. An intense positive immunohistochemical staining of progesterone receptor was detected in some ductal and stromal cells in male MG.

Conclusion: In albino rat, the male mammary gland was well developed as female despite of the normal levels of the steroid hormones and without drug supplementation or endocrinal disturbance. This condition can provide fundamental information about a physiological type of gynecomastia that does not need hormonal replacement and may need only cosmetic surgical intervention.
\end{abstract}

Keywords: Male rat, mammary gland, growth factors, prolactin, progesterone, whole mount carmine alum

\section{Introduction}

The MG has been of great interest to generations of biologists from many disciplines. The structure of the male and female MG can provide a sensitive indicator of endocrinal disturbance [1]. This gland is particularly suited for studying developmental processes as it is readily amenable to experimental manipulation and can be easily accessed. Furthermore in animals, MG tissue is abundant because there are 6 pairs in each animal [2]. In females, a major part of MG development occurs postnatal, with distinct periods of intensive morphogenesis taking place at puberty and during pregnancy and lactation [3]. A course of ductal development includes multiple stages of proliferation and morphogenesis that are largely directed by concurrent alterations in key hormones and growth factors. Estrogen 
hormone is responsible for ductal elongation and bifurcation of MG [4]. While, progesterone hormone is responsible for lateral branching and alveologenesis of MG [5]. Further alveologenesis and differentiation of the luminal mammary epithelial cells into milk producing cells during late pregnancy require prolactin hormone [3]. EGF, IGF I and TGFa factors are potent mitogenic factors for both normal and transformed (neoplastic) mammary epithelium either in vivo [6] or in vitro [7].

Histologically, in virgin female animal, MG tissue contains epithelium and stroma. The mammary epithelial cells forming lactiferous ducts are bi-layered epithelium, with the inner luminal cells facing a central cavity and surrounded by the outer basal, myoepithelial cells. It also harbors stem and progenitor cells, which are the source of both luminal and myoepithelial cells [8]. The stroma includes fibrous connective tissue, and a wide variety of cell types, including inter- and intralobular fibroblasts, adipocytes, endothelial cells, and innate immune cells [9].

In male of most mammals, a rudimentary mammary structure is encountered; however the male albino rat MG is unique in displaying marked development (physiological gynecomastia) and in showing great sexual dimorphism [10]. Gynecomastia is a female like enlargement of the male breast resulting from increased parenchyma, stroma or fat. It is a common problem in the male population, particularly in young adults. Enlarged man breast can cause functional problems, psychosocial discomfort and fear of malignancy. So; it is the most common cause for seeking medical advice for a breast condition in men [11]. Despite the fact that there are no great quantitative differences between men and women either in progesterone secretion or serum progesterone levels, a little is known about the physiology, endocrinology, and pharmacology of progesterone and progestins in male gender or men especially in mammary gland development [12].

Being an organ designed to deliver nourishment and passive immunity to mammal's infants, most discussions of the functional and developmental anatomy and histology of the mammary gland focused on the female and not on the male one [13].

The aim of the present study was to detect causes and importance of mammary gland development in adult male albino rat to relate this normal appearance to gynecomastia in human. We hypothesized that histological examination of mammary glands in both sexes via whole mount carmine alum technique; H\&E and MT stains will clarify structural differences. Moreover, analysis of serum levels of estrogen, progestrone and prolactin hormones and EGF, IGF I and TGFa tissue proteins and immune-staining for ER and PR could explain the causes of male mammary gland proliferation. We expected that the levels of tested steroid hormones and growth factors of both sexes may be equal or show slight differences.

\section{Materials and methods}

In this study, 28 adult albino rats of average weight 200-220 $\mathrm{gm}$ were used. The animals were obtained from the animal house, Faculty of Medicine, Zagazig University, Zagazig, Egypt. The animals were kept under strict care and cleaning measures. They were housed in hygienic cages according to the guidelines for animal research issued by the National Institute of Health and approved by Animal Ethics Committee, Zagazig University.

\section{Chemicals \\ For whole mount carmine alum staining}

Carmine (Aldrich Chemical Co Ltd, Gillingham Dorset England) and aluminum potassium sulfate (BDH Chemicals, Ltd, Poole, England) were purchased from Algomhuria co (Mohafza st, Zagazig, Egypt).

\section{For hematoxylin and eosin staining}

Harris hematoxylin (Park Scientific Limited, Northampton, UK) and Eosin (Sigma-Aldrich chemie, Steinheim, Germany) were purchased from Algomhuria Co (Mohafza st, Zagazig, Egypt).

\section{For immunohistochemical staining}

Anti-progesterone and estrogen antibodies, (Novacastra Laboratories Ltd, UK) were purchased from Sigma office (Egyptian International Center for Import, Cairo, Egypt). Mayer's hematoxylin (Sigma-Aldrich chemie, Steinheim, Germany)were purchased from Algomhuria co (Mohafza st, Zagazig, Egypt).

\section{Experimental procedure}

The rats were separated into two groups:

Female group: 14 rats.

Male group: 14 rats.

The female group was sacrificed at estrus stage under anesthesia by intraperitoneal injection of pentobarbitone sodium $60 \mathrm{mg} / \mathrm{kg}$ [14]. To determine the estrus stage in female rats, they were co-cycled for preparation of vaginal smears. The vaginal smears were taken via vaginal lavage with distilled water and were transferred to glass slides and allowed to dry at room temperature. Once dry, they were immediately stained with crystal violet stain. Microscopically, three types of cells could be recognized: epithelial cells, cornified cells and leukocytes. Prominence of cornified cells indicated the estrus stage [15].

Serological analysis of serum ERB, PRA and PRL hormones Venous blood samples were withdrawn from the retro-orbital sinus by capillary tube and collected in clean glass centrifuge tubes. Blood samples were allowed to clot at room temperature for 30 minutes and then, the sera were stored at $-20^{\circ} \mathrm{C}[16]$.

\section{Histochemical analysis of EGF, IGF I and TGF $\alpha$ tissue protein}

Small biopsies of the right mammary glands were weighed, homogenized in 20 volumes (wt/vol) of PBS at $37^{\circ} \mathrm{C}$ and centrifuged at $15,000 \mathrm{X} \mathrm{gm}$ for $20 \mathrm{~min}$ at $4^{\circ} \mathrm{C}$; then, the supernatants were stored at $-20^{\circ} \mathrm{C}[16]$. Both serological and histochemical 
analyses were done in (Biochemistry Department, Faculty of Medicine, Cairo University, Egypt).

\section{Whole mount carmine alum staining technique}

The left dissected mammary glands were immediately spread on large glass slides, fixed in Carnoy's fixative (25\% glacial acetic acid, $75 \%$ absolute ethanol), at room temperature in fume hood for 2 days then, washed in $70 \%$ ethyl alcohol for 1 hour, rinsed in distilled water (DW) for $30 \mathrm{~min}$, stained in carmine alum stain for 2 days, dehydrated in ascending grades of alcohol and cleared in xylene at least for 2 days. To prepare carmine alum stain; $1 \mathrm{gm}$ carmine and $2.5 \mathrm{gm}$ aluminum potassium sulfate in $450 \mathrm{ml}$ distilled water was boiled for $20 \mathrm{~min}$. Final volume was adjusted to $500 \mathrm{ml}$ with DW [17].

\section{Histological study}

In both sexes, the remaining parts of right fourth, fifth and sixth inguinal mammary glands were fixed overnight in $10 \%$ neutral buffered formalin and processed into paraffin blocks. They were cut into $5 \mu \mathrm{m}$ sections and stained with $\mathrm{H} \& \mathrm{E}, \mathrm{MT}$ [18] and immunohistochemical procedure [19].

\section{Immunohistochemistry technique}

To examine the distribution of Progesterone and Estrogen receptors, streptavidin-biotin immunoperoxidase system was used. In brief, deparaffinized sections $3 \mu \mathrm{m}$ thick were rehydrated in a descending graded alcohol series and washed twice with distilled water for 5 min each time. Antigen retrieval was conducted for all sections using heat-induced epitope retrieval, through immersion of tissue sections in citrate buffer, $\mathrm{pH} \mathrm{6.0,} \mathrm{autoclaved} \mathrm{at} 105^{\circ} \mathrm{C}$, for $20 \mathrm{~min}$. Endogenous peroxidase was blocked by incubating sections in $3 \% \mathrm{H}_{2} \mathrm{O}_{2}$ in absolute methanol for $30 \mathrm{~min}$ at $4^{\circ} \mathrm{C}$, followed by flushing with water. After blocking solution treatment (biotinylated rabbit anti-mouse secondary antibody), the sections were incubated overnight at $4^{\circ} \mathrm{C}$ with the primary antibody for ER and PR (monoclonal antibodies of estrogen and progesterone) diluted in $0.01 \mathrm{M}$ phosphate buffered saline (PBS). The sections for negative controls were incubated in $0.01 \mathrm{M}$ PBS without primary antibody. Finally, the mammary glands were visualized with 3,3'-diaminobenzidine tetrahydrochloride $\mathrm{H}_{2} \mathrm{O}_{2}$ solution for $3 \mathrm{~min}$. Sections were washed in distilled water, and finally counterstained slightly with Mayer's hematoxylin [19].

\section{Morphometric analysis}

The image analyzer computer system Leica Qwin 500 (Leica Imaging system, Ltd, Cambridge, England) was used to measure the terminal ductules thickness using whole mount carmine alum stained slides (Pathology Department, Faculty of Dentistry, Cairo University, Cairo, Egypt).

\section{Statistical analysis}

Serum levels of steroid hormones, tissue levels of growth factors and terminal ductules thickness were statistically analyzed. The obtained data were expressed as mean values \pm standard deviation and analyzed using unpaired student's $T$-test. Difference was considered to be significant at $\mathrm{P}<0.05$ between groups.

\section{Results \\ Serological results}

The male group revealed a high statistically significant decrease of PRL hormone $(P<0.001)$ and a statistically significant decrease of ERB hormone levels $(P<0.05)$ in comparison to female group. Progesterone hormone serum level showed no statistically significant $(P>0.05)$ difference between both groups (Table 1) and (Histogram 1). Statistically significant decreases regarding tissue EGF, IGF I and TGFa in male group were detected (Table 2) and (Histogram 2).

\section{Whole-mount results}

The whole-mount carmine alum stained slides showed that the ductal tree of the female MG reached the edge of the fat pad (Figure 1a). The ductal tree of male MG nearly filled half of the fat pad (Figure 1b). In the female mammary gland, extensively branched lactiferous duct in an apparent mass of fat pad was detected. The primary ducts were slightly thick and relatively short. The secondary ducts were thinner and longer than the primary ducts. The tertiary ducts were numerous, long, very thin and nearly formed the ductal tree (Figure 2a). A thin long tertiary duct bifurcated at its end into subtending duct that further bifurcates into long thin terminal ducts interlacing with large amount of fat pad (Figure 2b). In the male mammary gland, less extensively branched ductal

Table 1. Statistical analysis of serum levels of ERB, PRA and PRL hormones.

\begin{tabular}{l|ll|ll|ll}
\hline \multirow{2}{*}{ Hormones } & \multicolumn{2}{|c|}{ Female } & \multicolumn{2}{c|}{ Male } & \multirow{2}{*}{ T test } & P Value \\
\cline { 2 - 7 } & Mean \pm SD & Range & Mean \pm SD & Range & & \\
\hline Estradiol $17 \beta(\mathrm{pg} / \mathrm{ml})$ & $40.2 \pm 10$ & $19.2-55.8$ & $8.9 \pm 2.3$ & $4.6-11.1$ & 9.9 .65 & $0.013^{*}$ \\
Progesterone $(\mathrm{ng} / \mathrm{ml})$ & $32.4 \pm 16$ & $14.8-64.4$ & $29.7 \pm 9$ & $11.4-39.8$ & 8.18 & 0.554 \\
Prolactin $(\mathrm{pg} / \mathrm{ml})$ & $84.9 \pm 10$ & $64.9-104.9$ & $25.8 \pm 7$ & $11.4-39.8$ & 234.42 & $<0.001^{\star *}$ \\
\hline
\end{tabular}

This table shows a highly significant difference of Prolactin level as $\mathrm{P}<0.001$, and a significant difference of Estradiol $17 \beta$ level as $P<0.05$. A non significant difference of Progesterone level between both groups is detected as $\mathrm{P}>0.05$. 


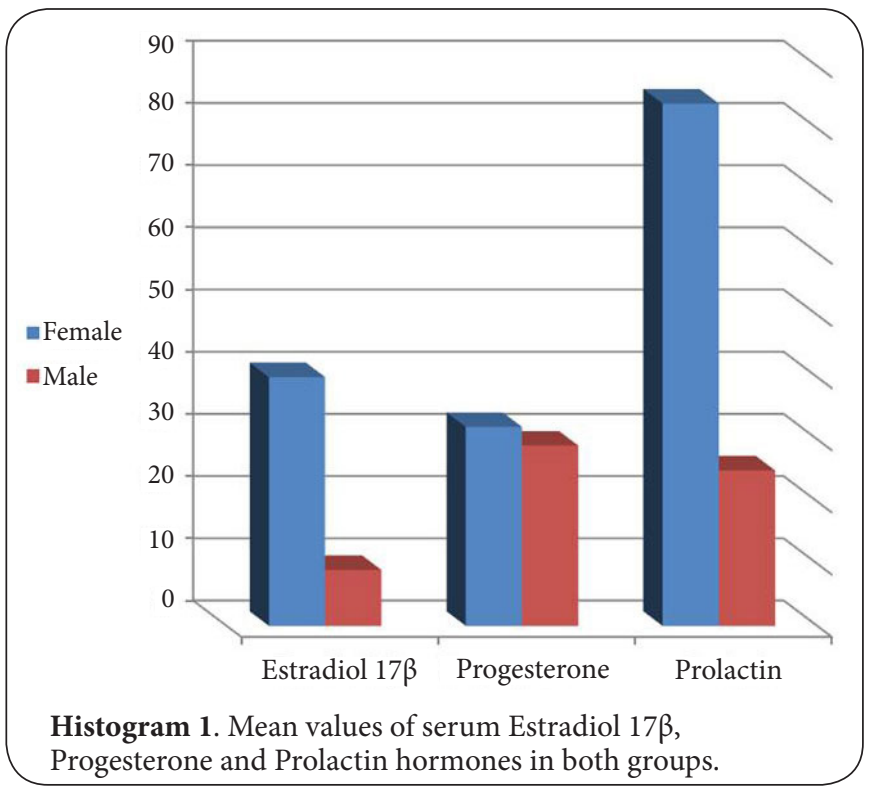

Table 2. Statistical analysis of tissue EGF, IGF I and TGFa in both groups.

\begin{tabular}{c|ll|ll|ll}
\hline \multirow{2}{*}{ Factors } & \multicolumn{2}{|c|}{ Female } & \multicolumn{2}{c|}{ Male } & \multirow{2}{*}{ T test } & P Value \\
\cline { 2 - 7 } & Mean \pm SD & Range & Mean \pm SD & Range & & \\
\hline EGF & $0.48 \pm 0.1$ & $0.28-0.68$ & $0.24 \pm 0.01$ & $0.22-0.26$ & 7.55 & $0.023^{\star}$ \\
IGF I & $0.63 \pm 0.1$ & $0.23-1.03$ & $0.53 \pm 0.1$ & $0.33-0.73$ & 5.0 & $0.036^{\star}$ \\
TGFa & $0.25 \pm 0.04$ & $0.21-0.33$ & $0.12 \pm 0.01$ & $0.1-0.14$ & 9.97 & $0.01^{*}$ \\
\hline
\end{tabular}

This table shows significant differences regarding tissue EGF, IGF I and TGFa as $\mathrm{P}<0.05$.

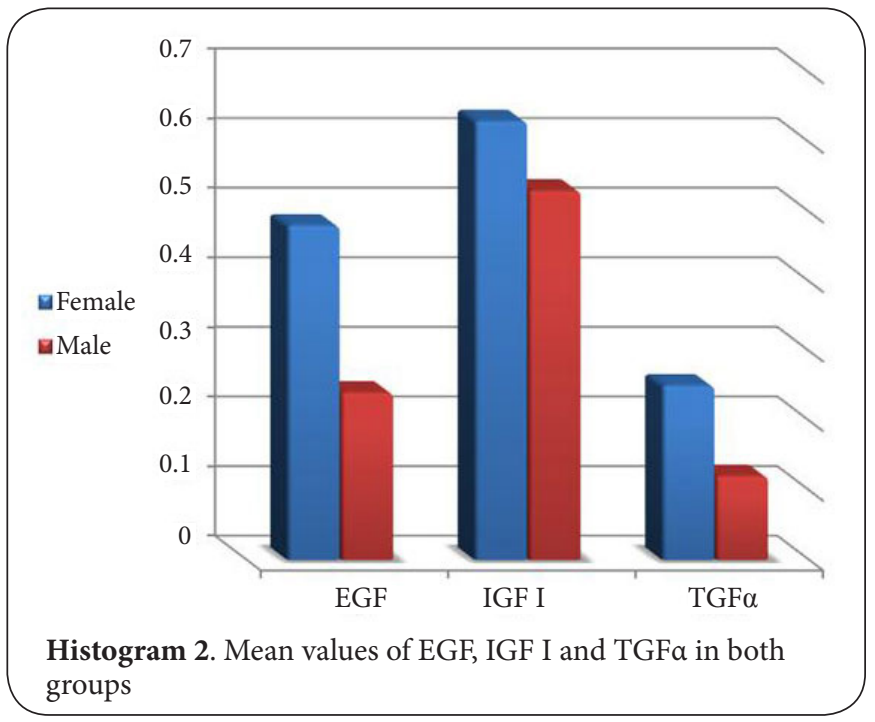

tree in a little mass of fat pad was nearly reached the edge. The primary, secondary and tertiary ducts were indistinct from each other and nearly had the same thickness and

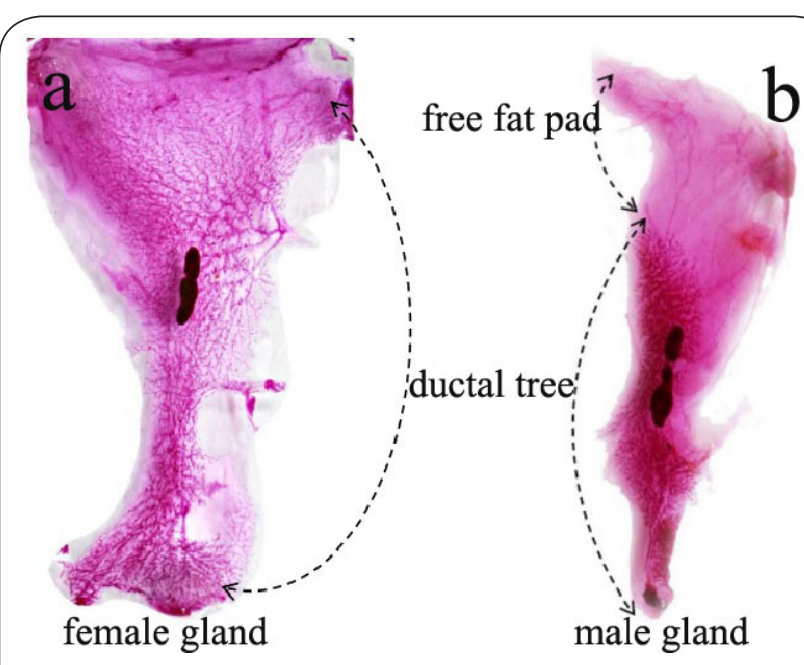

Figure 1. The ductal tree of female (a) and male (b) mammary glands according to whole-mount carmine alum stain.

(a): The ductal tree nearly reaches the edge of the fat pad.

[Carmine Alum stain].

(b): The ductal tree nearly fills half of the fat pad.

[Carmine Alum stain].

length while the terminal ducts were well defined (Figure 2c). Arborization of apparently thick subtending ducts into irregular outlined short ducts showed small lobules at their ends and their walls had irregular shaped tiny lateral lobulation (Figure 2d). Smooth outlined terminal ducts, terminal end buds and lateral buds had thin stalks and bifurcated smooth bulbous structure at its ends were seen in female rat mammary gland (Figure 3). Large irregularly outlined lobules at the end of terminal ductules were characteristic to male mammary gland (Figure 4).

\section{Histological results \\ $H \& E$}

Examination H\&E stained sections of female gland showed thick capsule and vascular adipose connective tissue stroma containing ducts (Figure 5a). Scattered tubular duct system was surrounded by thick dense eosinophilic fibrous stroma which was full of fibroblasts (Figure $\mathbf{5 b}$ ). The male gland showed less developed stroma, thin capsule and thin periductal fibrous stroma. Many alveoli and inguinal lymph node were also seen (Figure 5c). Lobulo-alveolar structures were predominant in male gland (Figure $\mathbf{5 d}$ ).

The female mammary gland ducts were lined by stratified epithelium. The luminal cells were cuboidal and had large central rounded nuclei. The basal cells were flat with flat nuclei. Flat nuclei of fibroblasts were also seen in the fibrous stroma (Figure 6a). The male mammary gland large ducts were lined by multiple layers of large vacuolated luminal epithelial cells. Their nuclei were large and rounded. Luminal and ductal apoptotic cells and acidophilic secretion filling the lumen were detected. Thin layer of fibrous stroma around the ducts was seen. 


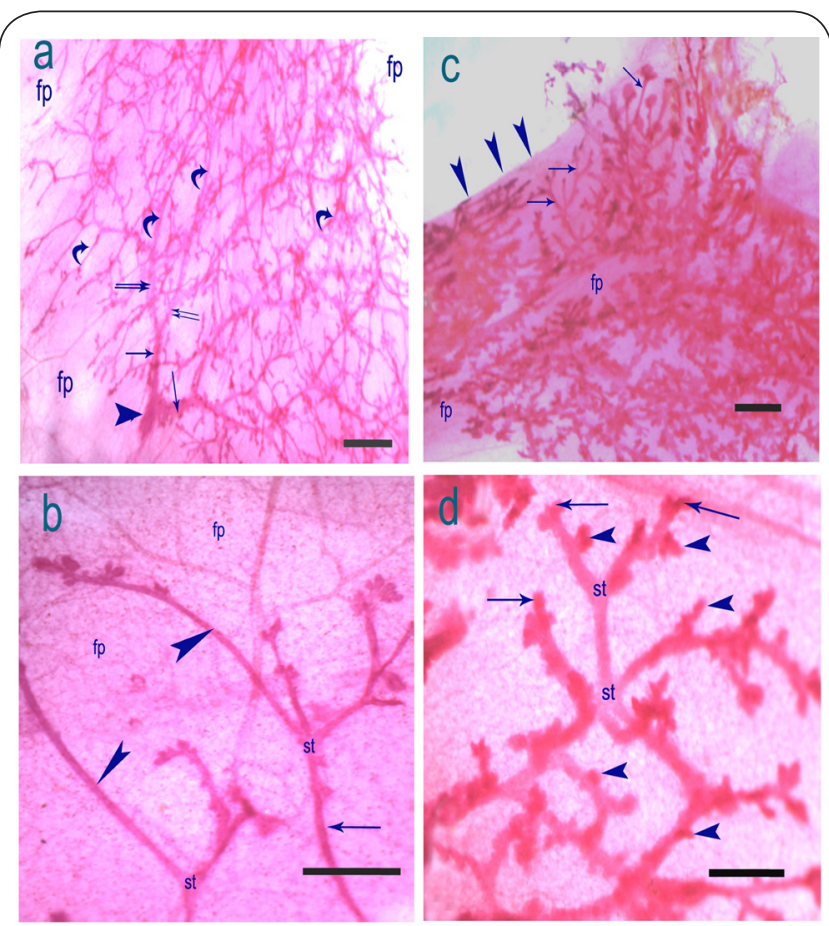

Figure 2. The female (a,b) and male (c,d) mammary glands according to whole mount Carmine alum stain.

(a): Showing extensively branching lactiferous duct (arrow head) in an apparent mass of fat pad (fp). The primary ducts (arrows) are slightly thick and relatively short. The secondary ducts (double arrows) are thin and long. The tertiary ducts (curved arrows) are numerous, long, very thin and nearly formed the ductal tree. [Carmine Alum stain, X10. Bar, $1.2 \mathrm{~mm}]$. (b): Showing a thin long tertiary duct (arrow) bifurcating into subtending ducts (st) which bifurcates into long thin terminal ducts (arrow heads) interlacing with fat pad (fp). [Carmine Alum stain, X40. Bar, 2.4mm].

(c): Showing less branched ductal tree in a little mass of fat pad (fp) nearly reached the edge(arrow heads). The primary, secondary and tertiary ducts are indistinct and nearly of the same thickness and length while the terminal ducts are well defined (arrows). [Carmine Alum stain, X10. Bar, 1.2mm]. (d): Showing thick subtending ducts (st) arborized into irregular outlined short ducts that end as small lobules (arrows). Their walls have irregular tiny lateral lobulation (arrow heads). [Carmine Alum stain, X40. Bar, 1.8mm].

Thin outlined white unilocular adipocytes with large cytoplasmic fat droplets and peripheral nuclei surrounded the fibrous stroma (Figure $6 \mathbf{b}$ ). Thick ductal fibrous stroma surrounded the small ducts and numerous small blood vessels were observed (Figure $\mathbf{6 c}$ ). Very thin stroma and a few numbers of fibroblasts around the small ducts which were lined by two layers of vacuolated cells with rounded nuclei were seen. Deeply acidophilic secretion filling the lumen was also seen (Figure $6 \mathrm{~d}$ ).

\section{Masson's trichrome}

The female mammary gland showed thick layer collagen fibers

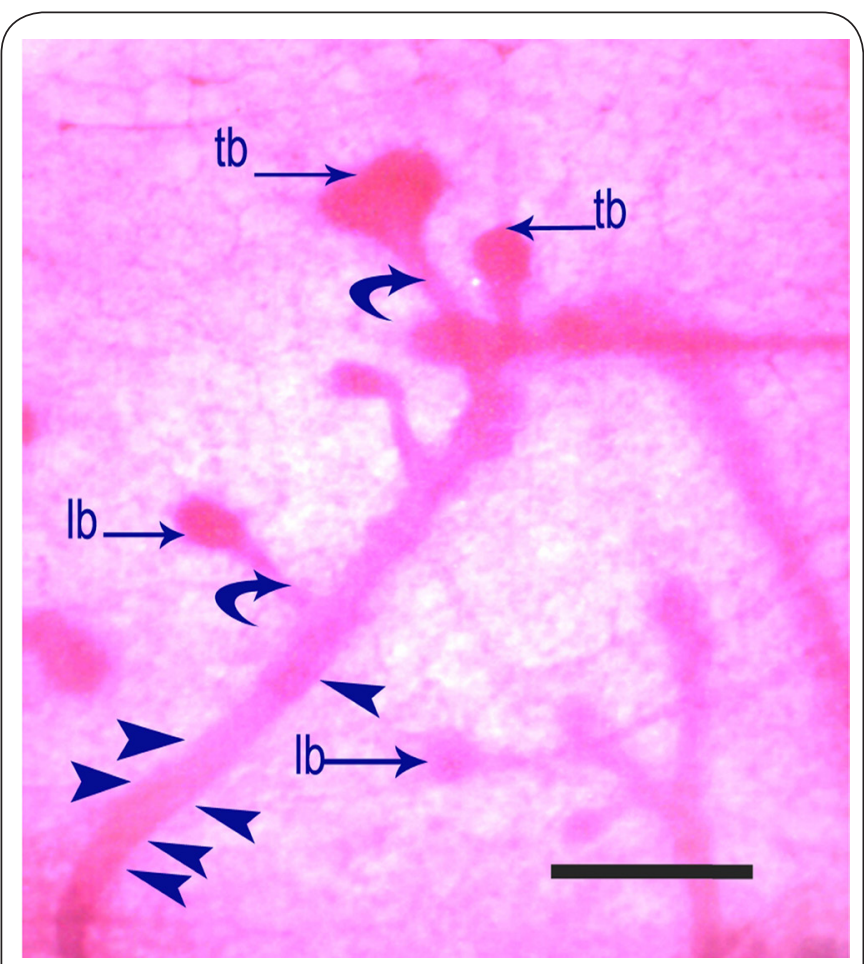

Figure 3. The mammary gland of female rat according to whole-mount carmine alum stain: Showing smooth outlined terminal ducts (arrow heads). The terminal bulbous end buds (tb) and lateral buds (lb) have thin stalks (curved arrows). [Carmine Alum stain, X80. Bar, $4.8 \mathrm{~mm}$ ].

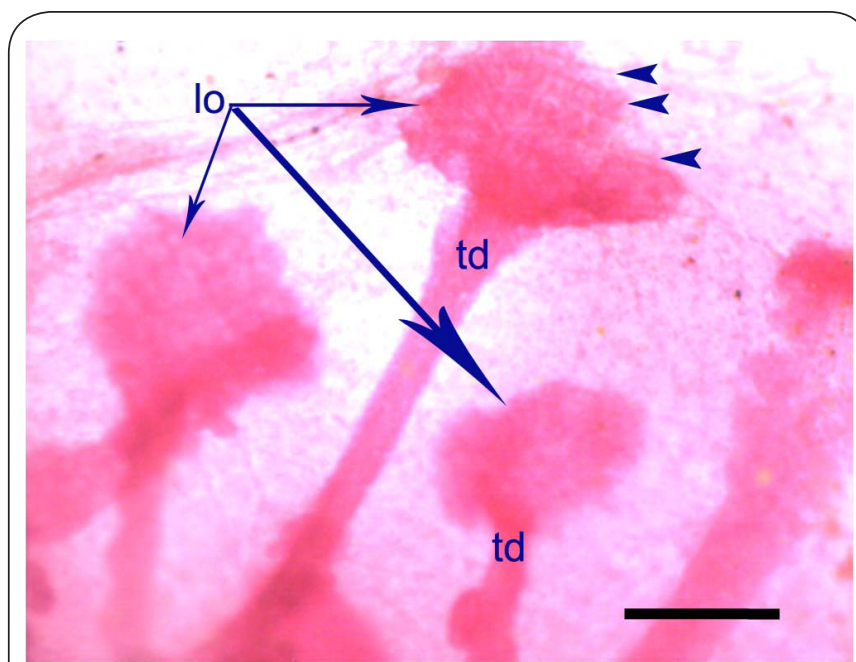

Figure 4. The mammary gland of male rat according to whole-mount carmine alum stain: Showing large irregularly outlined (arrow heads) lobules (lo) at the end of terminal ductules (td). [Carmine Alum stain, X80. Bar, $4.8 \mathrm{~mm}$ ].

around the blood vessels and ducts (Figure 7a). In male group, the alveoli were devoid of connective tissue. The collagen fibers around the ducts were thin while, around blood vessels were thick (Figures $\mathbf{7 b}$ and $7 \mathrm{c}$ ). 

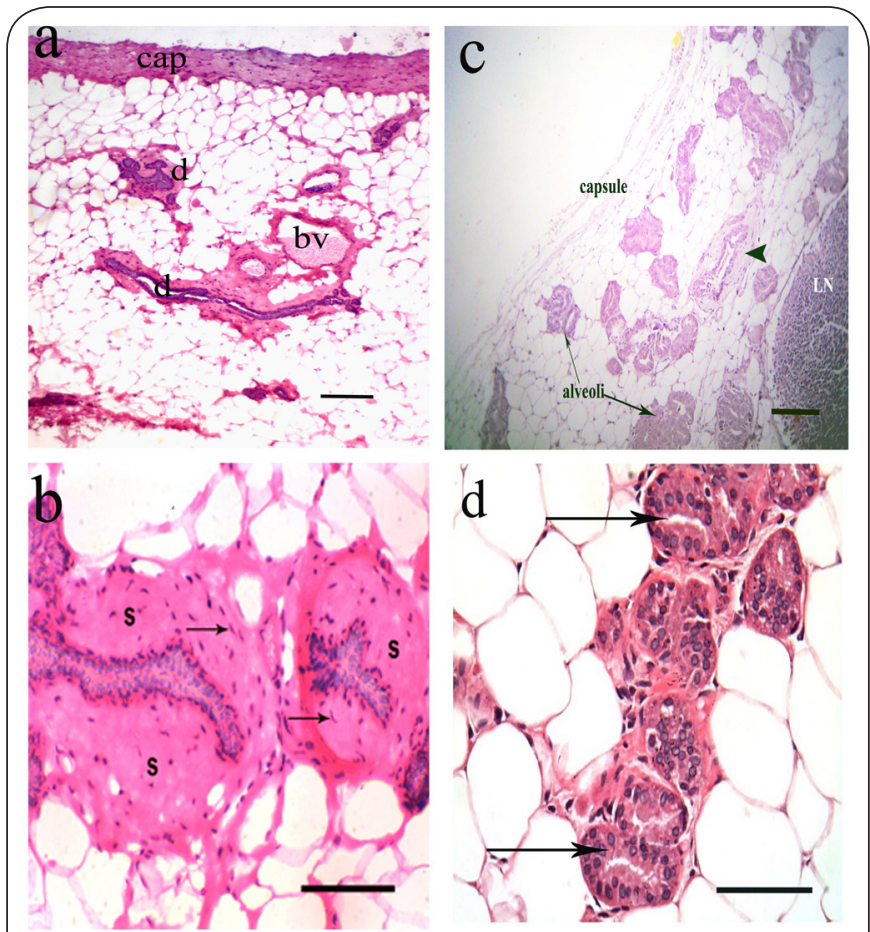

Figure 5. The structure of female $(a, b)$ and male $(c, d)$ mammary gland sections according to H\&E stain.

(a): Showing thick capsule (cap), vascular stroma (bv) and ducts (d). [H\&E, X100. Bar, $100 \mu \mathrm{m}]$.

(b):Showing scattered duct system surrounded by dense eosinophilic stroma (s) which is full of fibroblasts (arrows).

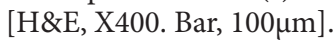

(c): Showing thin capsule, thin periductal fibrous stroma (arrow head), many alveoli and inguinal lymph node (LN).

[H\&E, X100. Bar, $100 \mu \mathrm{m}]$.

(d): Showing lobulo-alveolar structure (arrows) predominant in male gland. [H\&E, X400. Bar, $100 \mu \mathrm{m}$ ].

\section{Immunohistochemical results}

The female mammary gland showed positive reaction for progesterone in some ductal cells (Figure 8a) and a dense positive reaction for estrogen in most of ductal cells (Figure $\mathbf{8 b}$ ). In male group, patchy distributed pattern was seen for progesterone positive reaction in some ductal epithelial cells, in luminal secretion and in fibroblastic stromal cells. A negative reaction for estrogen in the ductal epithelium and a weak positive reaction in periductal stroma were observed (Figures $8 \mathrm{c}$ and $8 \mathrm{~d}$ ).

\section{Discussion}

In most mammals, the male mammary gland is regarded as a rudimentary organ without ascribed functions; as a result, research on the development and endocrine responses of male mammary glands has been limited [20]. In female, the MG is an important tool for examining some developmental, endocrinal and tumor biological aspects [21]. So, most discussions of the functional and developmental anatomy and histology of the mammary gland were focused on the female and not on the male [10].

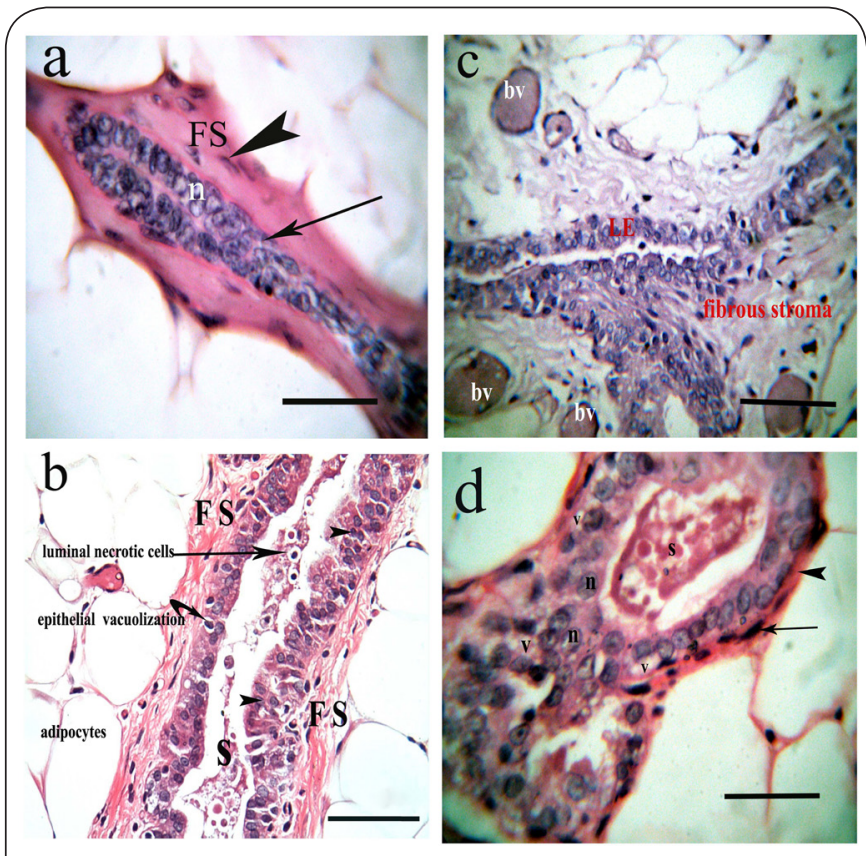

Figure 6. The structure of ducts of female (a) and male (b-d) mammary gland sections according to $\mathrm{H} \& \mathrm{E}$ stain.

(a): Showing the duct is lined by stratified epithelium. The luminal cells are cuboidal with large central rounded nuclei (n). The basal cells are flat with flat nuclei (arrow). Flat nuclei of fibroblasts (arrow head) are seen in the fibrous stroma (FS).

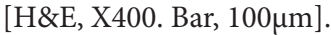

(b): Showing the large duct is lined by multiple layers of vacuolated large luminal epithelial cells (closed arrow) with large rounded nuclei (arrow heads). Luminal and ductal necrotic cells (arrows) and acidophilic secretion (S) are seen in the lumen. The fibrous stroma (FS) around the duct is thin. Large unilocular adipocytes surrounded the fibrous stroma are noted. [H\&E, X400. Bar, $100 \mu \mathrm{m}]$.

(c): Showing the small duct (LE) is surrounded by thick fibrous

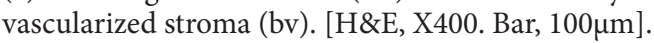

(d): Showing the subtending duct is lined by vacuolated cells (v) with rounded nuclei (n). Very thin stroma (arrow head), a few number of fibroblasts (arrow) and deeply acidophilic

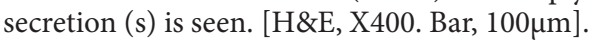

Determination of estrous cycle stages is emerging as an important consideration when working on female animals in several research areas. In the present work, the time of sacrifice was at the estrus stage in the female group [15]. Unlike all other stages, during estrus stage, the rat serum prolactin was found to be the highest as determined by enzyme immunoassay. Additionally, it represents the most differentiated mammary gland state [21].

Necessity of Prolactin [22] and Progesterone [23] for lobuloalveolar development of female MG was reported. So, blood samples from both groups were collected to determine concentrations of hormones known to be involved in mammary gland growth and differentiation. Despite of a highly statistically significant decrease in Prolactin hormone and a non significant decrease in Progesterone serum levels in 


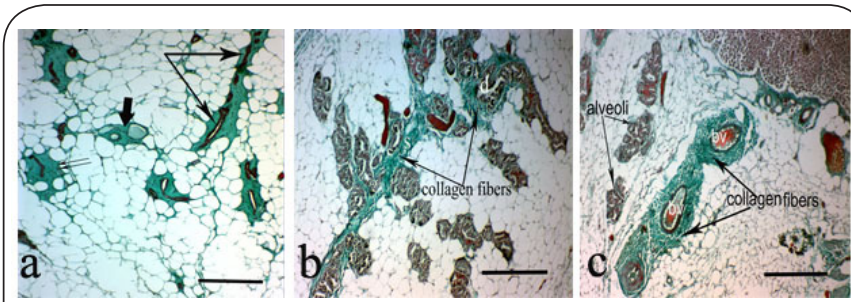

Figure 7 . The female (a) and male (b,c) mammary gland sections according to MT stain.

(a): Showing the fibrous stroma around the ducts (arrows) and the blood vessels (thick arrow) is thick collagenous. [Masson's

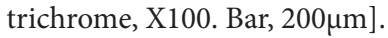

(b): Showing a thin layer of collagen fibers around the ducts.

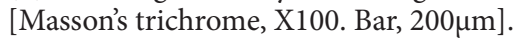

(c): Showing a thick layer of collagen fibers around blood vessels while, alveoli are devoid of connective tissue [Masson's trichrome, X100. Bar, $200 \mu \mathrm{m}]$.

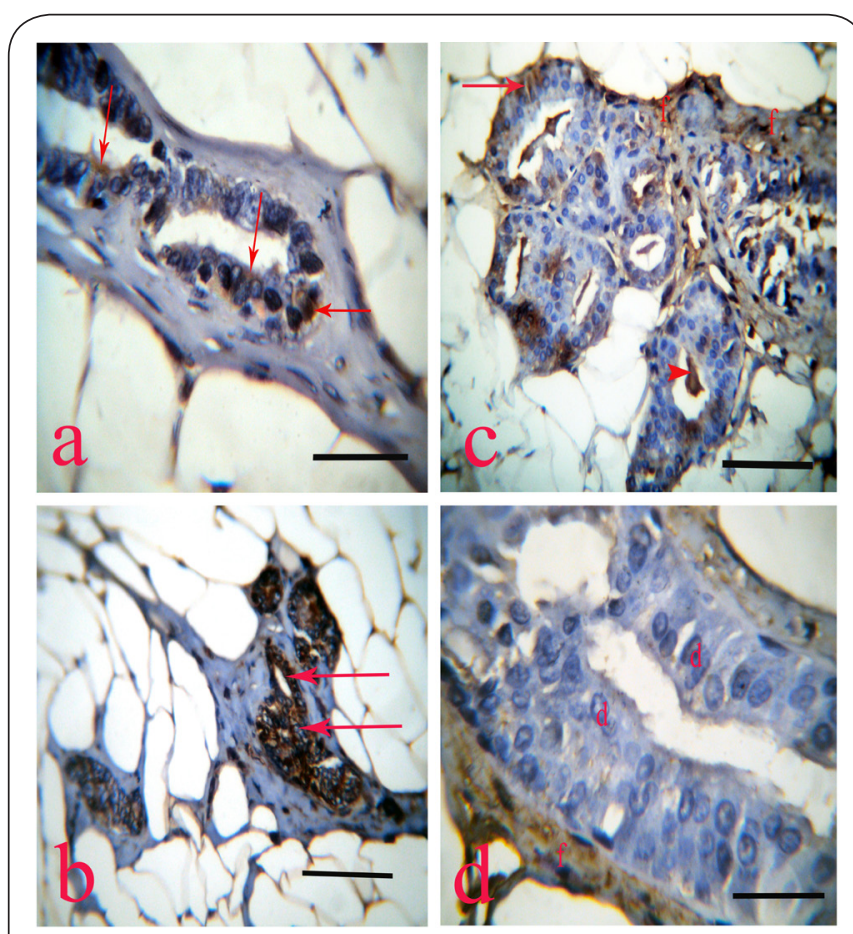

Figure 8. Immunodetection of progesterone and estrogen $\beta$ receptors of female $(a, b)$ and male $(c, d)$ mammary gland sections.

(a): A positive reaction for progesterone receptor in some ductal cells (arrows) is seen. [Progesterone receptor immunostaining, $\mathrm{X} 400$. Bar, $100 \mu \mathrm{m}]$. (b): A tense positive reaction for Estrogen $\beta$ receptor in most of ductal cells (arrows) is seen. [Estrogen $\beta$ receptor immunostaining, X400. Bar, $100 \mu \mathrm{m}]$. (c): A patchy distributed pattern for progesterone receptor positive reaction in some ductal epithelial cells (arrow), in luminal secretion (arrow head) and in fibroblastic stromal cells (f) is noticed. [Progesterone receptor immunostaining, X400. Bar, 100 $\mu \mathrm{m}$ ]. (d): A negative reaction for estrogen $\beta$ receptor immunostaining in the ductal epithelium (d) a weak positive in reaction in periductal stroma (f) is detected. [Estrogen $\beta$

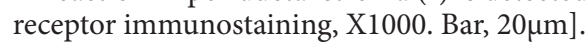

male rats, their mammary glands exhibited lobulo-alveolar secretory parenchyma. Knight and Peaker [24] referred this unique sex-specific morphology of rat male MG to tissue sensitivity that increases the susceptibility and responsiveness of mammary gland to various endogenous hormonal stimuli. Their explanation was confirmed by our data obtained from immunostained sections in male glands (intense positive immunoexpression to progesterone receptors in all parenchyma).

In the current study, EGF, IGF I and TGFa tissue protein, were measured as these factors were documented as potent mitogenic factors for both normal and neoplastic mammary epithelium either in vivo [7] or in vitro [8]. Interestingly, a significant increase in these factors was detected in female group in comparison to male group.

It is well known that both estrogen [25] and epidermal growth factor [26] are responsible for extensive branching and ductal elongation of the mammary glands. In addition, progesterone is responsible for lobulo-alveolar development [27]. In the current work, immuno-staining of PRA and ER $\beta$ receptors were carried out aiming to reveal the exact causes of male mammary growth in rats. A striking observation was the strong positive expression of PR in male mammary luminal epithelial cells, luminal secretion and peri-alveolar stroma. Similar patterns of expression were observed for PRA in human female mammary gland [28]. The presence of PRA all over the mammary cells may provide a clue for lobuloalveolar predominance in male glands. In the male group of present work, the negative immunoexpression to ER in the luminal epithelium and the weak positive reaction to ER in periductal stroma can be correlated with the stunted ductal growth of the male mammary ductal tree [25].

Whole-mount technique is considered the most reliable technique used to visualize epithelial ductal and alveolar structures against a translucent fatty background as it readily reveals the extent of ductal elongation, branching, and alveolar development and allows strict quantitative measurements [17]. Based upon analysis of whole-mount slides, the male MG ducts were short, with irregular outline and nearly of the same thickness and length. The terminal ductules were well defined. These data were in accordance with Shyamala [23]. He recorded thick short ducts with extensive lateral branching and large numbers of terminal buds in transgenic mice with an excess PRA expression. Also, in knocked out estrogen receptor a animals, hypoplastic development of the epithelial tree was demonstrated [25]. The limited branching and length of male mammary ducts were related to decreased periductal collagenous connective tissue stroma [29]. Furthermore, estrogen drives extensive growth and branching of female mammary gland [25].

The development of the mammary ductal tree depends on stromal-epithelial interactions, and these interactions are important in embryonic and postnatal evolvement. The stromal compartment is composed of mesenchymal cells (fibroblasts and leukocytes) and extra-cellular matrix as laminin, 
fibronectin, collagen and proteoglycans [30]. In male albino rats, less developed stroma in the form of thin capsule and thin periductal stroma around the large ducts were in accordance with [1]. They suggested that extra-cellular matrix is involved in the interactions between the mammary cells and their environment.

The ducts of male mammary gland showed two different lining epithelium in relation to their size: the large ducts were lined by multiple layers of vacuolated luminal epithelial cells with large and rounded nuclei. The smaller ducts were lined by doubled layers of low epithelial cells. These features in male mammary gland structure were documented [31]. These features referred probably to a higher sensitivity of male rat mammary tissue to steroid hormones than other male mammals e.g., mice [32]. A completely different picture of male mammary glands in other male rodents was recorded. Their mammary glands were described as a rudimentary mammary glandular tissue [3].

The cells lined large male mammary ducts were characterized by abundant foamy eosinophilic cytoplasm containing distinct variable sized vacuoles. Their lumina were mostly contained evidence of secretory activity with apoptotic bodies and fragmented epithelial cells. These histological changes were identified in rats' female mammary gland after Dehydroepiandrosterone (DHEA) treatment [33]. They showed that, the potent stimulatory effects of androgens on lobuloalveolar as well as ductal development in the female rat mammary gland are due to intracrine conversion of DHEA into active sex steroids with predominant or even possibly exclusive androgenic activity in the mammary gland. They added that local formation of androgen and estrogen through intracrine activity in rats plays a major role in these histological features.

Masson's trichrome staining revealed that the male periductal stroma was much reduced relative to that in female, especially around small ducts and alveoli. The previous hypotheses proposed that the mammary gland development and branching is partially dependent on the amount of extracellular matrix [34,35].

Gynecomastia is a proliferation of the glandular component of the male breast. In most cases, it is a pathological condition in response to increased level of estrogen or decreased level of testosterone [36], drugs e.g., ethionamide [37], spironolactone, cimetidine and ketoconazole [38] or increased endogenous Prolactin [39]. In the current work, evaluated steriodal hormones were within normal levels in both groups.

\section{Conclusion}

The results of the present study concluded that proliferation of male albino rat MG occurred despite of normal levels of its serum steroid hormones and without drug supplementation or any endocrinal disturbance. This condition can provide fundamental information about a physiological type of $g y-$ necomastia that does not need hormonal correction and may need only cosmetic surgical intervention. We recommended immuno-staining of breast biopsy in diagnosed cases of gynecomastia in men. In addition, further serological and histological investigations of male rat mammary tissue are needed to strengthen our data.

\section{Competing interests}

The authors declare that they have no competing interests.

Authors' contributions

\begin{tabular}{|l|c|c|c|}
\hline Authors' contributions & ZAG & SMA & NME \\
\hline Research concept and design & $\checkmark$ & -- & -- \\
\hline Collection and/or assembly of data & $\checkmark$ & -- & -- \\
\hline Data analysis and interpretation & $\checkmark$ & $\checkmark$ & $\checkmark$ \\
\hline Writing the article & $\checkmark$ & $\checkmark$ & $\checkmark$ \\
\hline Design of figures & $\checkmark$ & -- & $\checkmark$ \\
\hline Critical revision of the article & $\checkmark$ & $\checkmark$ & $\checkmark$ \\
\hline Final approval of article & $\checkmark$ & $\checkmark$ & $\checkmark$ \\
\hline Statistical analysis & -- & $\checkmark$ & -- \\
\hline
\end{tabular}

\section{Acknowledgement}

We would like to thank Prof. Dr. Fadia Khalid Abdo for her English language editing and reviewing of the manuscript, Prof. Dr. Dalia Elrobi for morphometrical aid and Dr. Eman Elshahate for statistical aid.

\section{Publication history}

EIC: Giuseppe Musumeci, University of Catania, Italy.

Received: 14-Dec-2014 Final Revised: 29-Jan-2015

Accepted: 23-Feb-2015 Published: 03-Mar-2015

\section{References}

1. Lucas JN, Rudmann DG, Credille KM, Irizarry AR, Peter A and Snyder PW. The rat mammary gland: morphologic changes as an indicator of systemic hormonal perturbations induced by xenobiotics. Toxicol Pathol. 2007; 35:199-207. | Article | PubMed

2. Brisken $\mathrm{C}$ and $\mathrm{O}^{\prime}$ Malley $\mathrm{B}$. Hormone action in the mammary gland. Cold Spring Harb Perspect Biol. 2010; 2:a003178. | Article I PubMed Abstract I PubMed Full Text

3. Richert MM, Schwertfeger KL, Ryder JW and Anderson SM. An atlas of mouse mammary gland development. J Mammary Gland Biol Neoplasia. 2000; 5:227-41. | Article | PubMed

4. Forster C, Makela S, Warri A, Kietz S, Becker D, Hultenby K, Warner M and Gustafsson JA. Involvement of estrogen receptor beta in terminal differentiation of mammary gland epithelium. Proc Natl Acad Sci U S A. 2002; 99:15578-83. | Article I PubMed Abstract | PubMed Full Text

5. Beleut M, Rajaram RD, Caikovski M, Ayyanan A, Germano D, Choi $\mathrm{Y}$, Schneider $\mathrm{P}$ and Brisken $\mathrm{C}$. Two distinct mechanisms underlie progesterone-induced proliferation in the mammary gland. Proc Natl Acad Sci U S A. 2010; 107:2989-94. | Article | PubMed Abstract | PubMed Full Text

6. Vonderhaar BK. Local effects of EGF, alpha-TGF, and EGF-like growth factors on lobuloalveolar development of the mouse mammary gland in vivo. J Cell Physiol. 1987; 132:581-4. I PubMed

7. Valverius EM, Bates SE, Stampfer MR, Clark R, McCormick F, Salomon DS, Lippman ME and Dickson RB. Transforming growth factor alpha production and epidermal growth factor receptor expression in normal and oncogene transformed human mammary epithelial cells. $\mathrm{Mol}$ Endocrinol. 1989; 3:203-14. I Article I PubMed

8. Visvader JE. Keeping abreast of the mammary epithelial hierarchy and breast tumorigenesis. Genes Dev. 2009; 23:2563-77. I Article I PubMed Abstract | PubMed Full Text 
9. Sternlicht MD. Key stages in mammary gland development: the cues that regulate ductal branching morphogenesis. Breast Cancer Res. 2006; 8:201. | Article | PubMed Abstract | PubMed Full Text

10. Vandenberg LN, Schaeberle CM, Rubin BS, Sonnenschein C and Soto AM. The male mammary gland: a target for the xenoestrogen bisphenol $A$. Reprod Toxicol. 2013; 37:15-23. | Article | PubMed Abstract | PubMed Full Text

11. Arvind A, Khan MA, Srinivasan $K$ and Roberts J. Gynaecomastia correction: A review of our experience. Indian J Plast Surg. 2014; 47:5660. | Article | PubMed Abstract | PubMed Full Text

12. Oettel $M$ and Mukhopadhyay AK. Progesterone: the forgotten hormone in men? Aging Male. 2004; 7:236-57. | Article I PubMed

13. Masso-Welch PA, Darcy KM, Stangle-Castor NC and Ip MM. A developmental atlas of rat mammary gland histology. J Mammary Gland Biol Neoplasia. 2000; 5:165-85. | Article | PubMed

14. Ozmen J, Bobryshev YV, Lord RS and Ashwell KW. Identification of dendritic cells in aortic atherosclerotic lesions in rats with diet-induced hypercholesterolaemia. Histol Histopathol. 2002; 17:223-37. | Pdf | PubMed

15. McLean AC, Valenzuela N, Fai S and Bennett SA. Performing vaginal lavage, crystal violet staining, and vaginal cytological evaluation for mouse estrous cycle staging identification. J Vis Exp. 2012; e4389. I Article | PubMed Abstract | PubMed Full Text

16. Ingman WV, Wyckoff J, Gouon-Evans V, Condeelis J and Pollard JW. Macrophages promote collagen fibrillogenesis around terminal end buds of the developing mammary gland. Dev Dyn. 2006; 235:3222-9. | Article | PubMed

17. de Assis S, Warri A, Cruz MI and Hilakivi-Clarke L. Changes in mammary gland morphology and breast cancer risk in rats. J Vis Exp. 2010. Article | PubMed Abstract | PubMed Full Text

18. Bancroft JD and Layton C. The Hematoxylin and eosin. In: Suvarna SK, Layton C and Bancroft JD editors. Theory and Practice of histological techniques. $7^{\text {th }}$ ed., Churchill Livingstone of El Sevier. Philadelphia. Ch 10 and 11. 2013; 172-214.

19. Jackson $P$ and Blythe D. Immunohistochemical techniques. In: Suvarna SK, Layton C and Bancroft JD editors. Theory \& Practice of histological techniques. $7^{\text {th }}$ ed., Churchill Livingstone of El Sevier. Philadelphia. Ch. 18. 2013; 381-434.

20. Wang XJ, Bartolucci-Page E, Fenton SE and You L. Altered mammary gland development in male rats exposed to genistein and methoxychlor. Toxicol Sci. 2006; 91:93-103. | Article | PubMed

21. Fata JE, Leco KJ, Voura EB, Yu HY, Waterhouse P, Murphy G, Moorehead RA and Khokha R. Accelerated apoptosis in the Timp-3-deficient mammary gland. J Clin Invest. 2001; 108:831-41. | Article | PubMed Abstract | PubMed Full Text

22. Das $\mathrm{R}$ and Vonderhaar BK. Prolactin as a mitogen in mammary cells. $J$ Mammary Gland Biol Neoplasia. 1997; 2:29-39. | Article | PubMed

23. Shyamala G. Progesterone signaling and mammary gland morphogenesis. J Mammary Gland Biol Neoplasia. 1999; 4:89-104. | Article | PubMed

24. Knight $\mathrm{CH}$ and Peaker M. Development of the mammary gland. J Reprod Fertil. 1982; 65:521-36. | Article | PubMed

25. Feng $Y$, Manka D, Wagner KU and Khan SA. Estrogen receptor-alpha expression in the mammary epithelium is required for ductal and alveolar morphogenesis in mice. Proc Natl Acad Sci U S A. 2007; 104:14718-23. | Article | PubMed Abstract | PubMed Full Text

26. Walczak M, Pawlus B, Kędzia A and Walkowiak J. Active synthesis of epidermal growth factor in human mammary glands. Acta scientiarum polonorum technologia alimentaria. 2010; 9:237-241.

27. Aupperlee MD and Haslam SZ. Differential hormonal regulation and function of progesterone receptor isoforms in normal adult mouse mammary gland. Endocrinology. 2007; 148:2290-300. | Article | PubMed

28. Li S, Han B, Liu G, Ouellet J, Labrie F and Pelletier G. Immunocytochemical localization of sex steroid hormone receptors in normal human mammary gland. J Histochem Cytochem. 2010; 58:50915. | Article | PubMed Abstract | PubMed Full Text
29. Kass L, Erler JT, Dembo M and Weaver VM. Mammary epithelial cell: influence of extracellular matrix composition and organization during development and tumorigenesis. Int J Biochem Cell Biol. 2007; 39:198794. | Article | PubMed Abstract | PubMed Full Text

30. Couldrey C, Moitra J, Vinson C, Anver M, Nagashima K and Green J. Adipose tissue: a vital in vivo role in mammary gland development but not differentiation. Dev Dyn. 2002; 223:459-68. | Article | PubMed

31. Cardy RH. Sexual dimorphism of the normal rat mammary gland. Vet Pathol. 1991; 28:139-45. | Article | PubMed

32. Neumann F. Early indicators for carcinogenesis in sex-hormone-sensitive organs. Mutat Res. 1991; 248:341-56. | Article | PubMed

33. Sourla A, Martel C, Labrie $C$ and Labrie F. Almost exclusive androgenic action of dehydroepiandrosterone in the rat mammary gland. Endocrinology. 1998; 139:753-64. | Article | PubMed

34. Wiseman BS and Werb Z. Stromal effects on mammary gland development and breast cancer. Science. 2002; 296:1046-9. | Article | PubMed Abstract I PubMed Full Text

35. Muschler $\mathrm{J}$ and Streuli $\mathrm{CH}$. Cell-matrix interactions in mammary gland development and breast cancer. Cold Spring Harb Perspect Biol. 2010; 2:a003202. | Article | PubMed Abstract | PubMed Full Text

36. Nordt CA and DiVasta AD. Gynecomastia in adolescents. Curr Opin Pediatr. 2008; 20:375-82. | Article | PubMed

37. Dixit R, George J, Sharma AK, Chhabra N, Jangir SK and Mishra V. Ethionamide-induced gynecomastia. J Pharmacol Pharmacother. 2012; 3:196-9. | Article | PubMed Abstract | PubMed Full Text

38. Deepinder $F$ and Braunstein GD. Drug-induced gynecomastia: an evidence-based review. Expert Opin Drug Saf. 2012; 11:779-95. | Article I PubMed

39. Carlson HE. Approach to the patient with gynecomastia. J Clin Endocrinol Metab. 2011; 96:15-21. | Article | PubMed

\section{Citation:}

Gouda ZA, Ahmed SM and Elghonaimy NM. Characterization of adult male albino rat mammary gland: a histological and serological study. J Histol Histopathol. 2015; 2:5. http://dx.doi.org/10.7243/2055-091X-2-5 